\title{
Histochemical characteristics of the vitellogenic oocytes of the bluefin tuna, Thunnus thynnus L.
}

\section{Características histoquímicas de los ovocitos vitelogénicos del atún rojo, Thunnus thynnus L.}

\author{
Carmen Sarasquete ${ }^{1 *}$ \\ M. Luisa González-de-Canales ${ }^{2 * *}$ \\ Carmen Piñuela ${ }^{1}$ \\ J. Antonio Muñoz-Cueto ${ }^{2}$ \\ Carmen Rendón ${ }^{2}$ \\ Evaristo L. Mañanós ${ }^{3}$ \\ F. J. Rodríguez-Gómez ${ }^{2}$ \\ Emilio Pascual ${ }^{1}$ \\ ${ }^{1}$ Instituto de Ciencias Marinas de Andalucía, CSIC \\ Polígono Rio San Pedro \\ Apdo oficial 11510 \\ Puerto Real, Cádiz, España \\ E-mail:*carmen.sarasquete@icman.csic.es;**marialuisa.gonzalez@uca.es \\ Unidad Asociada UCA-CSIC "Calidad Ambiental y Patología" \\ ${ }^{2}$ Departamento Biología Animal \\ Facultad de Ciencias del Mar y Ambientales \\ Universidad de Cádiz \\ ${ }^{3}$ Instituto de Acuicultura de Torre La Sal, CSIC \\ Ribera de Cabanes, Castellón \\ Recibido en septiembre de 2000; aceptado en julio de 2002
}

\begin{abstract}
Very little information is available with respect to dynamic aspects of oocyte development and to yolk composition of tuna species. Since histological approaches can offer considerable information about the ovarian development of fish, and because different cytochemical/immunohistochemical tests are suitable tools for proving the presence of different macromolecules in several organs/tissues/cells, they can be good biomarkers of the reproductive mechanism in fish. The present study investigates the presence and distribution of carbohydrates, proteins, glycoconjugates, lipids, calcium, iron and vitellogenin in the bluefin tuna, Thunnus thynnus oocytes during the synthesis of yolk (globules and granules) in the vitellogenic phase. During the initial vitellogenic phase, oocytes (diameter: $249 \pm 21.87 \mathrm{~mm}$ ) contain oil globules (or vacuoles) which consist exclusively of neutral lipids. During this phase very small yolk granules appear around the cytoplasm. Glycolipids, phospholipids, glycoproteins (Nacetyl-D-galactosamine -GalNAc- sugar residues), calcium, proteins rich in tyrosine, tryptophan, lysine, arginine, cysteine and cystine, as well as vitellogenin are the main constituents of the yolk granules and the follicular envelope of these real vitellogenic oocytes (diameter: $386 \pm 79.04 \mathrm{~mm}$ ). The intergranular cytoplasm of the vitellogenic oocytes also contain glycogen and glycoconjugates with Mannose -Man- and/or Glucose -Glc-; N-acetyl-D-galactosamine -GalNAc-; L-Fucose -Fuc- and Nacetyl-D-glucosamine -GlcNAc- and/or sialic acid -NANA- sugar residues. The zona radiata is mainly composed of proteins; in this cellular layer, scarce neutral glycoproteins and lipids (phospholipids/glycolipids) are also present.
\end{abstract}

Key words: ovary, vitellogenesis, histochemistry, proteins, lipids, vitellogenin, tuna.

\section{Resumen}

En las especies de túnidos existe muy poca información en relación a la dinámica del desarrollo de los ovocitos y a la composición del vitelo. Puesto que la histología puede aportar una amplia información sobre el desarrollo ovárico de peces y teniendo en cuenta que las técnicas citoquímicas/inmunohistoquímicas son herramientas adecuadas para observar la presencia de distintas macromoléculas en diferentes órganos/tejidos, ambos métodos (histología e histoquímica) pueden ser biomarcadores adecuados para conocer los mecanismos reproductivos de peces. En este trabajo se estudia la presencia y distribución de carbohidratos, proteínas, glicoconjugados, lípidos, calcio, hierro y vitelogenina en los ovocitos del atún rojo, Thunnus thynnus durante la síntesis de vitelo (glóbulos y gránulos) realizada durante la fase vitelogénica. Durante la fase inicial de la vitelogénesis, 
los ovocitos $(249 \pm 21.87 \mu \mathrm{m}$ de diámetro) contienen exclusivamente glóbulos (vacuolas) lipídicos compuestos exclusivamente por lípidos neutros. Durante esta fase, aparecen pequeños gránulos de vitelo en la perifería del citoplasma. Los principales componentes de los gránulos de vitelo y de la envoltura folicular de los ovocitos vitelogénicos $(386 \pm 79.04 \mu \mathrm{m}$ de diámetro $)$ son: glicolípidos, fosfolípidos, glicoproteínas (N-Acetil-D-galactosamina-GalNAc-), calcio, proteínas ricas en tirosina, triptófano, lisina, arginina, cisteína y cistina, así como vitelogenina (VTG). El citoplasma intergranular de los ovocitos vitelogénicos también contiene glucógeno y glicoconjugados con residuos de Manosa -Man-, y/o Glucosa -Glc-; N-Acetil-D-galactosamina GalNAc-; L-Fucosa -Fuc- y N-Acetilglucosamina -GlcNAc- y/o ácido siálico. La capa radiada está compuesta principalmente por proteínas y también contiene escasas glicoproteínas neutras y lípidos (fosfolípidos/glicolípidos).

Palabras clave: ovario, vitelogénesis, histoquímica, proteínas, lípidos, vitelogenina, atun.

\section{Introduction}

Tuna is one of the most important groups of species in the fisheries industry because of the large size, unique taste and high market price of the fish. The bluefin tuna, Thunnus thynnus L., is the largest species of tuna, reaching more than $3 \mathrm{~m}$ in total length, $500 \mathrm{Kg}$ in body weight and having a particularly high economic value. In recent years, bluefin tuna resources have been depleted by the increasing catch pressure. Its scarcity and commercial value along with very high growth rates make it promising for marine aquaculture purposes. Thunnus thynnus is widely distributed throughout the world, with two reproductive areas: (1) the Mediterranean Sea within two different zones: around the Baleares Islands and in the South of the Tirrene Sea, between Sicily and Sardinia, where spawning occurs in June and July; and (2) the Gulf of Mexico and South of Florida, where spawning occurs in April and May. Thunnus thynnus thynnus is the Atlantic tuna and Thunnus thynnus orientalis is the Pacific tuna subspecies. For spawning, African and European Atlantic tuna specimens migrate to the Mediterranean Sea (Davila, 1985).

The reproductive biology of bluefin tuna caught in traps at the South Atlantic coast and the Strait of Gibraltar (Spain) was thoroughly studied from 1956 to 1961 (Rodríguez-Roda, 1957; 1964; 1967). This author reported that first maturity (3 years old specimens) occurs at $98 \mathrm{~cm}$ for females and $105 \mathrm{~cm}$ for males. Tuna eggs have a diameter of 0.85 and $1.26 \mathrm{~mm}$. Between 5 and 30 millions of eggs/female is the batch fecundity for tuna specimens (5 and 12 years old). Hirota and Morita (1976) provided a brief histological description of the bluefin tuna (Thunnus thynnus) gonads from males and females captured in July. A six-stage maturity scale based on macroscopic criteria has been defined in ovaries of the yellowfin tuna, Tunnus albacares. The plurimodal frequency distribution of oocytes and intra-ovarian ova diameters strongly suggests the spawning of several egg batches in the same spawning season (Albaret, 1977). The frequency of ovaries containing postovulatory follicles has been used to estimate the spawning frecuency in yellowfin tuna, Thunnus albacares (Schaefer, 1996). Recently, interesting information was described during an annual cycle, enclosing maturation-spawning of Thunnus thynnus throughout the SW coasts of Spain (Barbate-Cadiz and Murcia) in relation to spermatogenesis, lipidic content (ovary, liver and muscle) and dynamic histological aspects of oocytes (Cárdenas et al., 2001; Mourente et al., 2002; Sarasquete et al., 2002).

\section{Introducción}

El atún es una de las especies más importantes en la industria pesquera, debido a su gran tamaño, sabor y alto precio en el mercado. El atún rojo, Thunnus thynnus L. es la mayor de las especies atunes, alcanzando más de $3 \mathrm{~m}$ de longitud total, $500 \mathrm{Kg}$ de peso y un valor económico muy elevado. Recientemente, debido a un exceso de capturas se ha observado un descenso de este recurso pesquero. $\mathrm{Su}$ escasez y alto valor comercial, junto con sus tasas de crecimiento elevadas, contribuyen a considerarla como una especie muy prometedora en acuicultura. Thunnus thynnus está ampliamente distribuido por todo el mundo con dos areas reproductivas: (1) el Mar Mediterráneo: alrededor de las Islas Baleares y el Sur del Mar Tirreno, entre Sicilia y Cerdeña, area en la que la reproducción se realiza en junio y julio; y (2) el Golfo de México y Sur de Florida, donde la reproducción se realiza en abril y mayo. Thunnus thynnus thynnus es el atún del Atlántico y Thunnus thunnus orientalis es la subespecie del Pacífico. Para su reproducción, los atúnes del Atlántico africano y europeo migran al Mar Mediterráneo (Davila, 1985).

La biología reproductiva del atún rojo capturado en almadrabas de la costa sur-Atlántica y el Estrecho de Gibraltar (España) ha sido ampliamente estudiada desde 1957 hasta 1961 (Rodríguez-Roda, 1957; 1964; 1967). Este autor observó que la primera madurez (ejemplares de 3 años) se produce en hembras de $98 \mathrm{~cm}$ y machos de $105 \mathrm{~cm}$. Los huevos del atún tiene un diámetro de 0.85 y $1.26 \mathrm{~mm}$ y su tasa de fecundidad, en ejemplares de 5 a 12 años, es de 5 a 30 millones de huevos/ hembra. En especies de túnidos, existe poca información relacionada con el desarrollo de los ovocitos y sobre la composición del vitelo. Hirota y Morita (1976) realizaron una pequeña descripción histológica de gonadas de machos y hembras del atún rojo, Thunnus thynnus, capturados en julio. Basándose en criterios morfológicos se han descrito 6 estados de madurez en ovarios del atún amarillo, Thunnus albacares. La frecuencia plurimodal de la distribución de ovocitos y el diámetro de los huevos intraováricos señalan que la puesta se realiza en varios grupos de ovocitos durante la misma estación reproductora (Albaret, 1977). La frecuencia de ovarios conteniendo folículos postovulatorios ha sido usada para estimar la frecuencia de reproducción en el atún, Thunnus albacores (Schaefer, 1996). Recientemente, se ha publicado interesante información durante el ciclo anual, incluyendo fases de maduración y puesta en ejemplares de Thunnus thunnus capturados en la costa SW española (Barbate-Cádiz y Murcia), en relación a la 
It has been shown that during oocyte development of fish, important cytoplasmic and nuclear changes occur (Wallace, 1978; Selman and Wallace, 1982; 1989; Selman et al., 1993), due essentially to the synthesis of yolk during the secondary growth phase. In this stage, oestrogens stimulate the synthesis of hepatic proteins (vitellogenin-VTG-), which are incorporated within oocytes (Selman and Wallace, 1982). The yolk chemical composition and the distribution of organic reserves during the reproductive cycle of teleosts have been studied by several authors (Chopra, 1958a, b; Guraya, 1965; Khoo, 1979; Gutiérrez et al., 1985; Mayer et al., 1988; González-deCanales et al., 1992; Sarasquete et al., 1993a, b, c; Grau et al., 1996; Lahnsteiner and Patzner, 1999). However, few immunocytochemical studies address VTG distribution during the reproductive cycle of fish (Hamazaki et al., 1985; Sarasquete et al., 1993b; Murata et al., 1994; Fujita et al., 1998; Susca et $a l ., 2001)$. Vitellogenin is a glycolipophosphoprotein complex which binds calcium and iron and is a precursor of yolk proteins. In stages of late oogenesis, oocytes of various teleosts contain VTG, and a number of smaller products that are derived from VTG, such as phosvitin, lipovitellin, glycovitellin, and one or two smaller yolk proteins $(\mathrm{Ng}$ and Idler, 1983; Lange et al., 1983; La Fleur et al., 1995). Alkaline phosphatase activity was observed in follicular cells (granulosa and theca) of oocytes of different fish species (Gillis and McKeonwn, 1990; Blanco, 1991), while widespread exocytotic activity from the bases of granulosa cells supported the suggestion that, at least during vitellogenesis, VTG was dephosphorylated within the follicular cells.

\section{Material and methods}

Ovaries, testis and livers of adult bluefin tuna (150-200 kg) caught during April and May $(n=18)$ in Almadrabas de Barbate (Cadiz, SW Spain) were fixed in buffered-formaldehyde $0.1 \mathrm{M} \mathrm{pH} 7.2$, for 24 hours. They were then dehydrated through graded alcohols, cleared in xylene and embedded in paraffin. Serial sections, 5-6- $\mu \mathrm{m}$ were cut in sagittal plane and mounted on gelatinized slides. Sections were rehydrated in distilled water. Haematoxylin-eosin and HaematoxylinVOF'Gutiérrez (light green-orange G-acid fuchsin) morphological techniques were performed according to Gutiérrez (1990).

Oocyte sizes were determined on histological slides using a Quantimet (Leica, Cambridge, UK) image analyser, by measuring the maximan and minimum oocyte-diameters.

The cytochemical tests for carbohydrates (PAS, diastase-

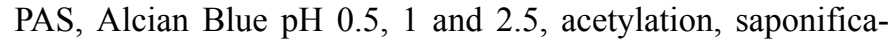
tion, chlorhydric hydrolysis, type $\mathrm{V}$ neuraminidase from Clostridium perfringens and bacterial hyaluronidase from Streptomices hyalurolyticus), as well as for glycoproteins (lectins), general proteins (Bromophenol Blue) and lysin-rich proteins (Ninhydrin-Schiff), tyrosine-rich proteins (Hgsulphate-sulfuric acid-sodium nitrate), tryptophan-rich proteins (P-dimethylaminobenzaldehyde), arginine-rich proteins $(1,2$ espermatogénesis, contenido lipídico (ovario, hígado y músculo) y dinámica del desarrollo ovocitario (Cárdenas et al., 2001; Mourente et al., 2002; Sarasquete et al., 2002).

Durante el desarrollo de los ovocitos de peces se producen importantes cambios citoplásmicos y nucleares (Wallace, 1978; Selman y Wallace, 1982; 1989; Selman et al., 1993), debido fundamentalmente a la síntesis de vitelo durante la fase secundaria de crecimiento. En esta fase, los estrógenos estimulan la síntesis de proteínas hepáticas (vitelogenina-VTG-), la cual es incorporada en los ovocitos (Selman y Wallace, 1982). La composición química del vitelo y la distribución de reservas orgánicas durante el ciclo reproductivo de teleósteos ha sido estudiada por diferentes autores (Chopra, 1958a, b; Guraya, 1965; Khoo, 1979; Gutiérrez et al., 1985; Sarasquete et al., 1993a, b, c; González-de-Canales et al., 1992; Grau et al., 1996; Mayer et al., 1988; Lahnsteiner y Patzner, 1999). Sin embargo, existen escasas referencias relacionadas con la localización inmunohistoquímica de vitelogenina -VTG- durante el ciclo reproductivo de peces (Hamazaki et al., 1985; Sarasquete et al., 1993b; Murata et al., 1994; Fujita et al., 1998; Susca et al., 2001). La VTG es un complejo glicolipofosfoproteico que se une al calcio y al hierro y es precursora de las proteínas del vitelo. En fases avanzadas de la vitelogénesis, los ovocitos contienen VTG, así como pequeños productos derivados de la degradación de la VTG, como fosvitina, lipovitelina y glicovitelina, y una o dos moléculas proteicas más pequeñas ( $\mathrm{Ng}$ y Idler, 1983; Lange et al., 1983; La Fleur et al., 1995). En las células foliculares (granulosa y teca) de ovocitos de diferentes teleósteos se observó actividad fosfatasa alcalina; la actividad exocitótica en las células de la granulosa parece sugerir que, al menos durante la vitelogénesis, la VTG es desfosforilada en las células foliculares (Gillis y McKneown, 1990; Blanco, 1991).

\section{Material y métodos}

Ovarios, testículos e hígado de ejemplares adultos del atún rojo, Thunnus thynnus (150-200 kg) capturados en las Almadrabas de Barbate (Cádiz, SO, España) fueron fijados en formaldehído tamponado con fosfatos $0.1 \mathrm{M}(\mathrm{pH}$ 7.2) durante 24 horas, deshidratados en series de alcohol, aclarados en xilol e incluidos en parafina. Se realizaron cortes coronales y sagitales que fueron montados en portaobjetos gelatinizados. Las secciones fueron hidratadas en agua destilada y como técnicas morfológicas se utilizaron Hematoxilina-eosina y Hematoxilina-VOF de Gutiérrez (verde-luz, orange G y fucsina ácida) según Gutiérrez (1990).

El tamaño de los ovocitos se calculó en portaobjetos usando el Analizador de Imagen Quantimet (leica, Cambridge, UK), realizando mediciones de los diámetros máximo y mínimo.

Para la distribución de carbohidratos se realizaron las siguientes técnicas citoquímicas: PAS, diastasa-PAS, Azul Alcian $\mathrm{pH} 0.5,1$ y 2.5, acetilación, saponificación, hidrólisis clorídrica, neuraminidasa-tipo $\mathrm{V}$ de Clostridium perfringens, hialuronidasa testicular de Streptomices hyalurolyticus, así 
napthoquinone-4-sulphonic acid salt sodium) and proteins rich in -SH and -S-S- (cisteine and cystine groups; Ferric ferricyanide-Fe III and Tioglycollate reduction) were performed. Histochemical reactions for lipids (Sudan Black B -SBB- and Oil Red O -ORO- for general and neutral lipids; Nile Blue and Luxol Blue for phospholipids and ChloramineT-performic acid-dinitrophenylhydrazine-PAS for glycolipids) were carried out. These methods were applied to sections directly processed in a cryostat (Cryocut E) and to sections from paraffin embedding. Cold acetone was used to remove neutral lipids; chloroform/methanol (1:1) to remove all lipids, and phospholipids were extracted with pyridin. Calcium was studied with Alizarin Red and Cobalt-Amonium sulphide techniques, and Iron was determined by the Prussian-Blue $\left(\mathrm{Fe}^{+3}\right)$ and the Turnbull-Blue $\left(\mathrm{Fe}^{+2}\right)$ methods. All techniques and reactions used in this study are described by Martoja and Martoja-Pierson (1970), Pearse (1985) and Bancroft and Stevens (1990).

For the analysis of glycoconjugates, sections were treated with $0.3 \%$ hydrogen peroxide for 10 minutes (to inhibit endogenous peroxidase) in Tris buffered saline (TBS) at $\mathrm{pH}$ 7.2. The sections were incubated for 30 minutes at room temperature in the presence of the following horseradish peroxidase-conjugated lectins (HPR-lectin conjugated) dissolved in TBS $\left(20 \mu \mathrm{mL}^{-1}\right)$ : Con A (Mannose-Man- and/or Glucose-Glc-), WGA (N-acetyl-D-glucosamine-GlcNAc- and/or sialic acid -NANA-), DBA (N-acetyl-D-galactosamine -GalNAc-) and UEA-I (L-Fucose -Fuc-). After three washes in TBS, peroxidase activity was visualized with TBS containing $0.05 \%$ 3,3'diaminobenzidine tetrahydrochloride and $0.015 \%$ hydrogen peroxide. Sections were washed in running tap water for 10 minutes, dehydrated, cleared and mounted in Eukitt. Controls were: omission of the respective lectin, substitution of lectin-HPR conjugates by TBS and treatments with different enzymes (Neuraminidase Type V, $0.9 \mathrm{U} / \mathrm{mg}$ Prot; $\beta$ Galactosidase Grade VI, 400 U/mg Prot; $\alpha$-Mannosidase Type III, $20 \mathrm{U} / \mathrm{mg}$ Prot; $\beta$-N-Acetylglucosamine, $0.25 \mathrm{U} / \mathrm{mg}$ Prot; and L-Fucosidase, $20 \mathrm{U} / \mathrm{mg}$ Prot). Lectins and enzymes were purchased from Sigma Chemical Co. St Louis, MO, USA.

Immunocytochemical staining was performed using a streptavidin-biotin-peroxidase complex method. Endogenous peroxidase activity was blocked with $1 \%$ hydrogen peroxide in Coons buffer $(0.01 \mathrm{M}$ Veronal, $0.15 \mathrm{M} \mathrm{NaCl})$ with $0.1 \%$ Triton $\mathrm{X}-100$ (CBT) for 30 minutes at room temperature. Before immunostaining, sections were transferred for 5 minutes to $\mathrm{CBT}$ and saturated with $0.5 \%$ casein for $30 \mathrm{~min}$. Sections were incubated overnight in a moist chamber at room temperature with a rabbit polyclonal antiserum raised against seabass vitellogenin (Mañanos et al., 1994) diluted 1:1000 in CBT with $0.5 \%$ casein. After several washes in CBT, sections were incubated for 1 hour at room temperature with biotinylated anti rabbit-IgG diluted 1:1000 in CBT- $0.5 \%$ casein. After washing in $\mathrm{CBT}$, sections were incubated for 1 hour at room temperature with streptavidin-peroxidase complex diluted 1:1000 in CBT. como técnicas para localizar glicoproteínas (lectinas), y proteinas (Azul de Bromofenol), proteínas ricas en lisina (Ninhidrina-Schiff), tirosina (Hg-sulfato-ácido sulfúriconitrato sódico), triptófano (P-dimetilaminobenzaldehido), arginina (1,2 Naftoquinona-4-ácido sulfónico-sal sódica) y grupos -SH y -S-S- (cisteina y cistina; Ferricianuro Férrico-Fe III y reducción con tioglicolato).

Las reacciones histoquímicas de lípidos (Negro Sudán B y Aceite Rojo O, para lípidos generales y lípidos neutros; Azul Nilo y Azul Luxol para fosfolípidos y Cloramina T-ácido perfórmico-dinitrofenilhidracina-PAS para glicolípidos) fueron realizadas en secciones procesadas directamente en el criostato (Criocut $\mathrm{E})$ y en secciones procedentes de la inclusión en parafina. Para la extracción de lípidos neutros se utilizó acetona fría; para la extracción de lípidos totales se usó cloroformo-metanol (1:1) y la piridina fue usada para la extracción de fosfolípidos. Para localizar calcio se utilizaron las técnicas de Rojo de Alizarina y Cobalto-Sulfuro Amónico; el hierro fue estudiado utilizando las técnicas de Azul de Prusia (Fe-III) y Azul de Turnbull (Fe-II). Todas las técnicas y métodos citoquímicos utilizados en este trabajo son descritos por Martoja y Martoja-Pierson (1970), Pearse (1985) y Bancroft y Stevens (1990).

Para el estudio de glicoconjugados, las secciones fueron tratadas con peróxido de hidrógeno al $0.3 \%$ durante 10 minutos (inhibición de la peroxidasa endógena) en tampon Tris salino a $\mathrm{pH}$ 7.2. Las secciones fueron incubadas durante 30 minutos a temperatura ambiente con las siguientes lectinas conjugadas con peroxidasa disueltas en TBS $\left(20 \mu \mathrm{mL}^{-1}\right)$ : Con A (Manosa -Man- y/o Glucosa -Glc-); WGA (N-Acetil-D-glucosamina -GlcNAc- y/o ácido siálico -NANA-); DBA (N-Acetil-Dgalactosamina -GalNAc-) y UEA-I (L-Fucosa -L-Fuc-). Después de tres lavados en TBS, la actividad peroxidásica se visualizó con tetrahidrocloruro de 3,3'diaminobencidina al $0.05 \%$ conteniendo peróxido de hidrógeno al $0.015 \%$. Las secciones fueron lavadas en agua durante 10 minutos, deshidratadas y montadas en Eukkit.

Los controles realizados fueron: omisión de las lectinas correspondientes, substitución de las lectinas marcadas con peroxidasa por TBS y tratamientos con diferentes enzimas (Neuraminidasa tipo V, $0.9 \mathrm{U} / \mathrm{mg}$ prot.; $\beta$-Galactosidasa Grado VI, $400 \mathrm{U} / \mathrm{mg}$ prot.; y L-Fucosidasa, $20 \mathrm{U} / \mathrm{mg}$ prot.). Las lectinas y enzimas proceden de Sigma Chemical Co, S. Luis, Mo, USA.

Las técnicas inmunocitoquímicas fueron realizadas utilizando la técnica de la streptavidina-biotina-peroxidasa. La peroxidasa endógena fue bloqueada utilizando peróxido de hidrógeno al $1 \%$ en tampon Coons (Veronal $0.01 \mathrm{M}$, ClNa $0.15 \mathrm{M})$ y Triton X-100 (CBT) durante 30 minutos a temperatura ambiente. Antes de realizar la inmunotinción, las secciones fueron tratadas durante 5 minutos con tampon CBT saturado con caseína al $0.5 \%$ durante 30 minutos. Las secciones fueron incubadas a temperatura ambiente, toda la noche, en una cámara húmeda con un anticuerpo policlonal antiVitelogenina de lubina obtenida en conejo (Mañanos et al., 
Finally, sections were washed with CBT followed by Tris-HCl $(0.05 \mathrm{M}, \mathrm{pH} 7.4)$ and peroxidase activity was observed in Tris$\mathrm{HCl} 0.05 \mathrm{M}, \mathrm{pH} 7.6$ containing $0.04 \%$ 4-chloro-1-naphtol and $0.005 \%$ hydrogen peroxide. Some sections were incubated with normal fish serum instead of the primary antibody.

\section{Results}

During the reproductive cycle of the bluefin tuna, $T$. thynnus L., vitellogenic oocytes were abundant in April and May. Initial vitellogenic oocytes measuring between 213 and $289 \mu \mathrm{m}(\mathrm{X}=249 \pm 21.87)$, containing lipid globules, and scarce and very small granules were observed around the cytoplasm. Those vitellogenic oocytes containing numerous yolk granules (glycophosphoproteins) throughout the cytoplasm, measured between 276 and $537 \mu \mathrm{m}(386 \pm 79.04)$. Yolk granules showed eosin (Haematoxylin-eosin) or orange $G$ (Haematoxylin-V.O.F'Gutiérrez) affinities, while lipidic globules were unstained with morphological dyes (figs. 1,2). The lipidic content (globules) of the vitellogenic oocytes was dissolved (vacuoles) during the paraffin embedding procedure. In fresh unfixed ovarian sections from criostat, these globules react with Oil Red O (ORO) and with Sudan Black B (SBB) and contain neutral lipids. The yolk granules showed a moderate sudanophilia (fig. 3) in the paraffin embedding sections incubated with pyridine and then stained with SBB. These results, as well as its tinctorial affinity to Nile Blue, Luxol Blue and Chloramine T-performic acid-dinitrophenylhydrazynePAS, indicate the presence of phospholipids and glycolipids.

Yolk granules showed a weak staining with PAS (fig. 4) and diastase-PAS reactions (presence of neutral glycoproteins/ glycolipids and absence of glycogen). They were strongly stained with protein techniques (figs. 5, 6 and 7) and unstained

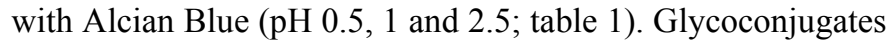
containing different sugar residues were detected in vitellogenic oocytes (figs. 8, 9 and 10). DBA lectin ( $\alpha$-GalNAc residues) was positive within proteic yolk granules of the vitellogenic oocytes (fig. 8). Other lectins, such as Con A ( $\alpha$ Man, $\alpha$-Glc, $\alpha$-GlcNAc), UEA ( $\alpha$-Fucose) and WGA $(\beta-$ GlcNAc, Sialic acid) were weakly positive or negative (figs. 9,10 ). Calcium techniques (fig. 11) were strongly positive within yolk granules, and very weak in the follicular envelope of the vitellogenic oocytes. The intergranular cytoplasm of these oocytes contain glycogen, lipids, proteins, glyconjugates containing different sugar residues (-Man- and/or -Glc-; GalNAc-, Fuc-, GlcNAc- and/or sialic acid-NANA-), as well as VTG, iron (Fe-III) and calcium (table 1).

In vitellogenic oocytes, the zona radiata shows a strong acidophilia/eosinophilia (H-E) and was mainly of a proteic nature. The zona radiata is formed by an internal part with affinity to fuchsine and another external with tinctorial affinity to light green (H-V.O.F.'Gutiérrez). The external portion of this layer gave a stronger PAS-positive reaction (neutral glycoproteins) than that of the internal portion, which contained abundant disulphyde groups (-S-S-), as well as
1994) diluida 1:1000 en CBT con caseína al 0.5\%. Después de varios lavados con CBT, las secciones fueron incubadas durante 1 hora a temperatura ambiente con IgG anti-conejo biotinizada y diluida 1:1000 en CBT -caseína al 0.5\%. Despues de un lavado con CBT, las secciones fueron incubadas durante 1 hora a temperatura ambiente con streptavidinaperoxidasa diluida 1:1000 en CBT. Finalmente las secciones fueron lavadas en CBT y Tris- $\mathrm{HCl}(0.05 \mathrm{M}, \mathrm{pH} 7.4)$. La actividad peroxidásica fue visualizada con 4-cloro-1-naftol (Sigma, S. Luis, MO) en Tris-ClH 0.05M, pH 7.6 y peróxido de hidrógeno al $0.005 \%$. Algunas secciones fueron incubadas con suero en vez del anticuerpo primario.

\section{Resultados}

Durante el ciclo reproductivo del atún Thunnus thynnus, los ovocitos vitelogénicos son abundantes en abril y mayo. Al iniciarse la vitelogénesis, los ovocitos $(213-289 \mu \mathrm{m}, \mathrm{X}=249 \pm$ $21.87 \mu \mathrm{m})$ contienen glóbulos lipídicos, y escasos y muy pequeños gránulos de vitelo en la perifería del citoplasma. A medida que progresa la vitelogénesis, en el citoplasma de los ovocitos $(276-537 \mu \mathrm{m}, \mathrm{X}=386 \pm 79.04 \mu \mathrm{m})$ comienzan a observarse numerosos gránulos de vitelo (glicofosfoproteico). Los gránulos de vitelo muestran afinidad por la eosina (Hematoxilina-eosina) o por el Orange G (Hematoxilina-VOF de Gutiérrez), pero los glóbulos lipídicos no mostraron afinidad por los colorante morfológicos (figs. 1,2). El contenido lipídico de los glóbulos se disuelve (vacuolas) durante el proceso de inclusión en parafina. En secciones de ovario frescas, sin fijar, y procesadas en el criostato, estos glóbulos reaccionan con Aceite Rojo O (ORO) y Negro Sudán B y contienen exclusivamente lípidos neutros. Los gránulos de vitelo mostraron una moderada sudanofília (fig. 3) en secciones procesadas en parafina, incubadas con piridina y posteriormente teñidas con Negro Sudán B. Estos resultados, así como su afinidad tintorial por el Azul Nilo, Azul Luxol y Cloramina T-ácido perfórmicodinitrofenilhidracina-PAS, indican la presencia, en los granos de vitelo, de fosfolípidos y glicolípidos.

Los gránulos de vitelo mostraron un débil reactividad al PAS (fig. 4) y diastasa-PAS (presencia de glicoproteínas neutras/glicolípidos y ausencia de glucógeno). Los gránulos de vitelo mostraron una gran reactividad a las reacciones de proteínas (figs. 5, 6, 7) y ausencia de tinción con el Azul Alcian ( $\mathrm{pH} 0.5,1$ y 2.5 ; tabla 1). En los ovocitos vitelogénicos se observaron glicoconjugados con diferentes residuos azucarados (figs. 8,9 y 10). La lectina DBA ( $\alpha$-GalNAc) fue positiva en los gránulos de vitelo de los ovocitos vitelogénicos (fig. 8). Otras lectinas, como la Con A ( $\alpha$ Man y/o $\alpha$ Glc, GlcNAc), UEA-I (L-Fuc) y WGA ( $\beta$ GlcNAc, ácido sialico) fueron débilmente positivas o negativas (figs. 9 y 10). Las técnicas del calcio (fig. 11) fueron fuertemente positivas en los gránulos de vitelo y débilmente en la capa folicular. En los ovocitos vitelogénicos del atún rojo, el citoplasma intergranular también contiene glucógeno, lípidos, proteínas, glicoconjugados (con 
Table 1. Histochemical results in the Vitellogenic Oocytes of Bluefin, Thunnus thynnus $L$.

Tabla 1. Resultados histoquímicos en los ovocitos vitelogénicos del atún rojo, Thunnus thynnus $\mathrm{L}$.

\begin{tabular}{|c|c|c|c|c|c|c|c|c|c|c|c|}
\hline & $\begin{array}{c}\text { Oil } \\
\text { globules }\end{array}$ & $\begin{array}{c}\text { Yolk } \\
\text { granules }\end{array}$ & $\begin{array}{c}\text { Intergranular } \\
\text { cytoplasm }\end{array}$ & $\begin{array}{l}\text { Follicular } \\
\text { envelope }\end{array}$ & $\begin{array}{l}\text { Zona } \\
\text { radiata }\end{array}$ & & $\begin{array}{c}\text { Oil } \\
\text { globules }\end{array}$ & $\begin{array}{c}\text { Yolk } \\
\text { granules }\end{array}$ & $\begin{array}{c}\text { Intergranular } \\
\text { cytoplasm }\end{array}$ & $\begin{array}{l}\text { Follicular } \\
\text { envelope }\end{array}$ & $\begin{array}{l}\text { Zona } \\
\text { radiata }\end{array}$ \\
\hline PAS & 0 & \pm & 1 & 1 & 1 & Cysteine & 0 & \pm & 1 & \pm & \pm \\
\hline Diastase-PAS & 0 & \pm & 0 & 1 & 1 & Cystine & 0 & 1 & 2 & 1 & 2 \\
\hline KOH-PAS & 0 & \pm & 2 & 1 & 1 & Lipids & $3\left(n^{*}\right)$ & 2 & 1 & 1 & 1 \\
\hline AA2.5 & 0 & 0 & 1 & \pm & 0 & Vitellogenin & 0 & 1 & 1 & 1 & 0 \\
\hline AA1 & 0 & 0 & 0 & 0 & 0 & Calcium & 0 & $1-2$ & \pm & \pm & 0 \\
\hline AA 0.5 & 0 & 0 & 0 & 0 & 0 & Iron-Fe $\mathrm{F}^{+2}$ & 0 & 0 & 0 & 0 & 0 \\
\hline Proteins & 0 & 3 & 2 & 2 & 3 & Iron-Fe ${ }^{+3}$ & 0 & 0 & \pm & 0 & 0 \\
\hline Lysine & 0 & \pm & + & \pm & \pm & DBA & 0 & 2 & 1 & 0 & 1 \\
\hline Arginine & 0 & \pm & + & \pm & \pm & Con A & 0 & \pm & 1 & \pm & $\pm(\mathrm{ZRI})$ \\
\hline Tyrosine & 0 & 3 & 2 & 2 & 2 & UEA & 0 & \pm & 1 & \pm & \pm \\
\hline Tryptophan & 0 & $2-3$ & 2 & 2 & 1 & WGA & 0 & 0 & \pm & \pm & 0 \\
\hline
\end{tabular}

Intensity of reaction: 0: negative; \pm : very weak or negative; 1 : weak; 2 : moderate; 3 : strong. $n^{\star}$ : neutral lipids; ZRI: Internal portion of the zona radiata.

glycoconjugates with Man and/or Glc sugar residues (table 1; figs. 1, 2, 6, 9).

Yolk granules, the intergranular cytoplasm and the follicular layer (fig. 12) showed a positive anti-seabass VTG immunostaining. Also the liver, and especially in the vascular system, showed a positive immunostaining against anti-VTG; a weak staining was also observed during April and May within the cytoplasm of hepatocytes from females (figs. 13, 14). During this time, negative results were observed in the liver and gonads from males.

\section{Discussion}

During the reproduction of teleosts, important morphological, histological and histochemical changes take place, as well as variations in the organic reserves (glycogen, proteins, lipids, etc.) of different organs and tissues, particularly the gonads and the liver. These changes lead to variations in the gonadosomatic and hepatosomatic indices, as well as to the synthesis of yolk (lipoglycophosphoproteic granules and lipid globules) on oocytes (De Vlaming et al., 1980; Blanco, 1991; Rosety et al., 1992; Alvarez, 1993; Muñoz-Cueto et al., 1996).

In bluefin tuna females, neutral lipids predominated over polar lipids (2-3:1) in the ovary and triacylglycerol and steryl/ wax ester were the major lipid classes (Mourente et al., 2002). According to these authors, during the reproductive cycle of this species, the lipid content increased significantly, 37.6 times, from immature to spawning stages, accumulating large quantities of steryl/wax esters. Lipid globules in the cytoplasm of the bluefin tuna vitellogenic oocytes only contain neutral lipids, which dissolve during the paraffin embedding procedure (vacuoles). This fact indicates that lipid globules could represent free unsaturated lipids (triacylglycerides, wax esters residuos de Man y/o Glc; GalNAc, L-Fuc, GlcNAc y/o ácido siálico, vitelogenina (VTG), hierro (Fe-III) y calcio (tabla 1).

La capa radiada (ZR) de los ovocitos vitelogénicos presenta una intensa acidofilia/eosinofilia (H-E) y su composición es de naturaleza fundamentalmente proteica.. La capa radiada está formada por una porción interna con fuerte afinidad por la fucsina y una porción externa con afinidad por el verde-luz del polícromo VOF de Gutiérrez. La porción externa presenta una mayor reactividad al PAS (glicoproteínas neutras) que la zona interna de la capa radiada la cual contiene abundantes grupos disulfuro (-S-S-), así como glicoconjugados con residuos de Mn y/o Glc (tabla 1; figs. 1, 2, 6 y 9).

Los granos de vitelo, el citoplasma intergranular y la capa folicular de los ovocitos vitelogénicos (fig. 12) mostraron una inmuroeactividad positiva frente al antisuero anti-VTG. Asimismo, se observó inmunoreactividad en el hígado, especialmente en el sistema vascular, y una debil reacción fue observada, durante abril y mayo, en el citoplasma de los hepatocitos de las hembras (figs. 13, 14). Durante este periodo, se observaron resultados negativos en la gónada y el hígado de machos.

\section{Discusión}

Durante la reproducción de teleósteos se producen importantes cambios morfológicos, histológicos e histoquímicos, así como variación en el contenido de reservas (glucógeno, proteínas, lípidos, etc.), especialmente en hígado y gónada. Estos cambios producen variaciones en los índices gonadosomático y hepatosómico y se relacionan con la síntesis de vitelo (gránulos lipoglicofosfoproteicos y glóbulos lipídicos) en los ovocitos. (De Vlaming et al., 1980; Blanco, 1991; Rosety et al., 1992; Alvarez, 1993; Muñoz-Cueto et al., 1996). 
and/or cholesterol), such as was observed in other fish species (Mayer et al., 1988; García-García, 1995; Muñoz-Cueto et al., 1996; Grau et al., 1996). Lipid globules were not present in vitellogenic oocytes of some fish species, while phospholipids and neutral lipids may or may not be observed in yolk granules of different teleosts (Khoo, 1979; Mayer et al., 1988; González de Canales et al., 1992; Sarasquete et al., 1993a; Muñoz-Cueto et al., 1996; Lahnsteiner and Patzner, 1999). In rabbifish, Siganus rivulatus (Lahnsteiner and Patzner, 1999), glycogen granules and few sialoglycoproteins are dispersed between lipid globules and yolk granules, such as was observed in vitellogenic oocytes of bluefin tuna specimens. Fish eggs use polysaccharides as energy resources, mainly from fertilization to hatching (Heming and Buddington, 1988).

On the other hand, the presence of glycoproteins, glycolipids and phospholipids in the yolk granules of the bluefin tuna vitellogenic oocytes, as in other fish species (Gutiérrez et al., 1985; Sarasquete et al., 1993a; Grau et al., 1996; Muñoz-Cueto et al., 1996), could be related to the vitellogenin. In several fish species (Dasmahapatra and Medda, 1982; Singh and Singh, 1990; Muñoz-Cueto et al., 1996), an increase in liver tryglicerides (energy source) and diglycerides (vitellogenin precursor) was observed during the reproductive period (vitellogenesis). Furthermore, it was indicated the importance of phospholipids and tryglicerides during vitellogenin synthesis, since they are functional components of this molecule (Haux and Norberg, 1985).

The yolk granules of bluefin tuna oocytes were weakly positive to PAS and diastase-PAS; moderately stained with lipid reaction (Sudan Black B) and strongly stained with several protein techniques (especially rich in tryptophan, tyrosine, arginine, cysteine and cystine). Yolk granules, intergranular cytoplasm and the follicular layer were also immunostained with anti-seabass-VTG and contained calcium. VTG is a glycolipophosphoprotein complex which binds calcium and iron; it is synthesized in the female liver during oogenesis/ vitellogenesis, released into the blood and transported to the ovaries forming the major constituent of the yolk (Hara and Hirai, 1978; Ng and Idler, 1983). Recently, an immunohistochemical staining of bluefin tuna ovaries with anti bluefin tuna-VTG serum (Susca et al., 2001) demonstrated a high cross-reactivity with yolk proteins, allowing the identification of vitellogenic oocytes. According to these authors, the immunoreactivity displayed by the follicular layer is of uncertain interpretation, possibly because this layer is not involved directly in the transfer of exogenous material into the oocytes (Abraham et al., 1984).

Hepatocytes have previously been identified as the site of exogenous vitellogenesis (VTG synthesis), while the vascular system has been identified as the transferral route between the liver and the ovary (Wallace, 1978). In bluefin tuna females, anti-seabass VTG immunostained the yolk granules, the follicular envelope and the intergranular cytoplasm of vitellogenic oocytes, as well as the liver (vascular system and hepatocytes). Wahli et al. (1998), using different monoclonal and polyclonal
En las hembras de atún rojo predominan los lípidos neutros sobre los polares (2-3:1) en el ovario, siendo los triacilglicéridos y esteril-ésteres/ceras las clases de lípidos predominantes (Mourente et al., 2002). Según estos autores, durante el ciclo reproductivo de esta especie, el contenido lipídico incrementa significativamente (37.6 veces) desde la época inmadura hasta la fase de puesta, acumulándose grandes cantidades de esterilésteres/ceras. Los glóbulos lipídicos presentes en el citoplasma de los ovocitos vitelogénicos del atún rojo sólo contienen lípidos neutros, los cuales son disueltos durante el proceso de inclusión en parafina (vacuolas). Estos lípidos, como se ha señalado en otras especies (Mayer et al., 1988; Grau et al., 1996; García-García, 1995; Muñoz-Cueto et al., 1996) corresponden a lípidos insaturados (triacilglicéridos, ésteres de ceras y/o colesterol). Los glóbulos lipídicos, fosfolípidos y lípidos neutros pueden estar presentes o ausentes en los gránulos de vitelo de diferentes teleósteos (Khoo, 1979; Mayer et al., 1988; González-de-Canales et al., 1992; Sarasquete et al., 1993a; Muñoz-Cueto et al., 1996; Lahnsteiner y Patzner, 1999). En Siganus rivulatus (Lahbsteiner y Patzner, 1999), como se observa en el citoplasma de los ovocitos del atún, dispersos entre los gránulos de vitelo y los glóbulos lipídicos, se detectan gránulos de glucógeno y sialoglicoproteínas. Según Heming y Buddington (1988), los huevos de lo peces utilizan los polisacáridos como fuente de energía, principalmente desde la fertilización hasta la eclosión.

Por otra parte, la presencia de glicoproteínas, glicolípidos y fosfolípidos en los granos de vitelo de los ovocitos del atún se puede relacionar, como en otras especies (Gutiérrez et al., 1985; Grau et al., 1996; Sarasquete et al., 1993a; Muñoz-Cueto et al., 1996) con la molécula de vitelogenina. En diferentes especies de peces (Dasmahapatra y Medda, 1982; Singh y Singh, 1990; Muñoz-Cueto et al., 1996) se observa un incremento de triglicéridos hepáticos (fuente de energía) y de diglicéridos (precursores de vitelogenina) durante el periodo reproductivo (fase vitelogénica). En este sentido, se ha señalado la importancia de los fosfolípidos y triglicéridos durante la síntesis de vitelogenina, puesto que son los componentes esenciales de dicha molécula (Haux y Norberg, 1985).

Los gránulos de vitelo de los ovocitos del atún rojo son débilmente positivos a las reacciones del PAS y el diastasaPAS (glicoproteínas neutras), moderadamente positivos a las reacciones de lípidos y fuertemente teñidos con las reacciones de proteínas (especialmente ricas en triptófano, tirosina, arginina, cisteína y cistina). Los gránulos de vitelo, el citoplasma intergranular y la capa folicular de los ovocitos vitelogénicos también reaccionan con el anticuerpo -VTG- y contienen calcio. La VTG es una glicolipofosfoproteína acomplejada con calcio y hierro; es sintetizada en el hígado de las hembras durante la ovogénesis/vitelogénesis, liberada a la sangre y transportada al ovario, para constiturir los principales componentes del vitelo (Hara y Hirai, 1978; Ng e Idler, 1983). Recientemente, se ha utilizado anti-VTG de atún rojo para identificar ovocitos vitelogénicos de dicha especie (Susca et al., 2001). Según estos autores, la inmunoreactividad 

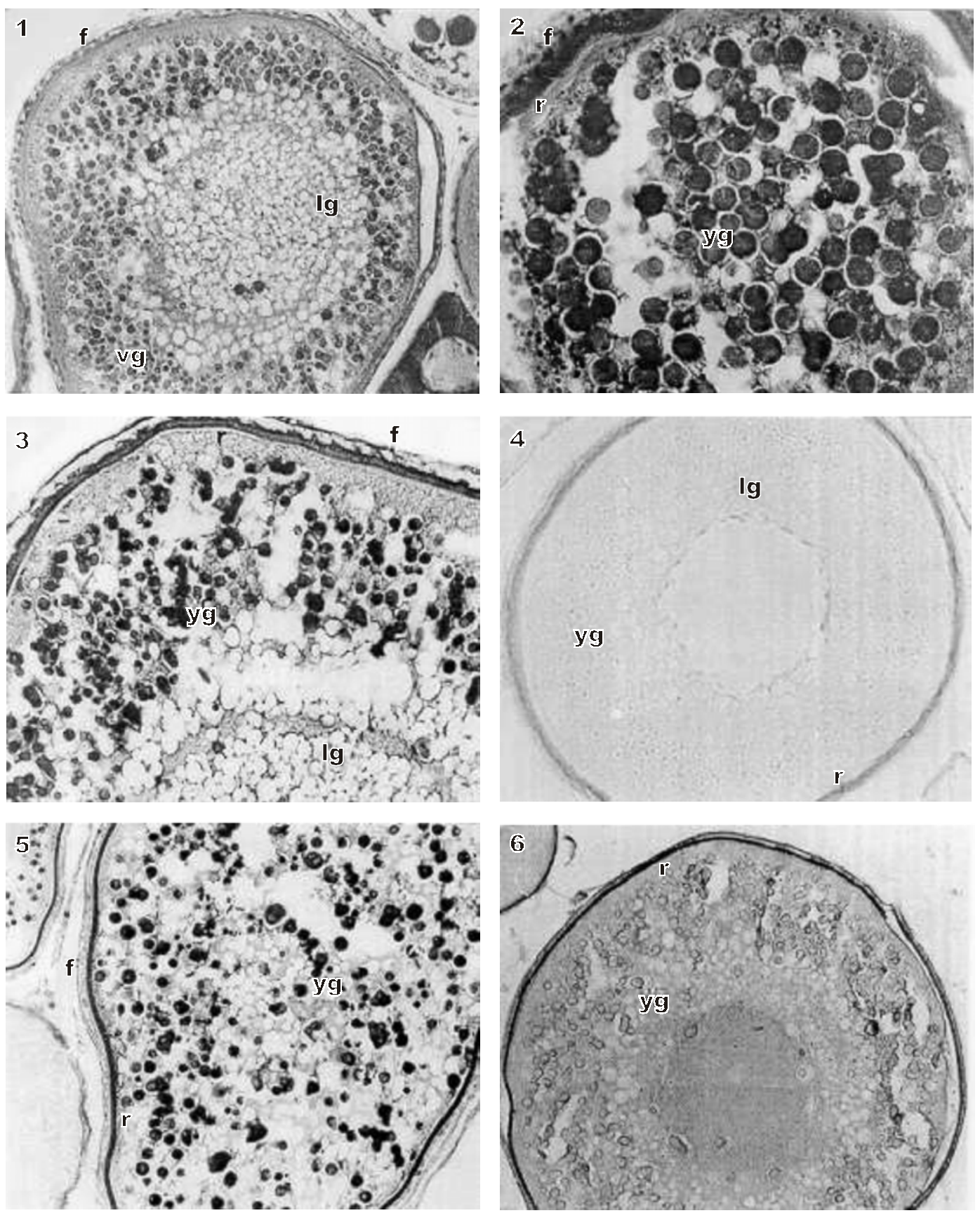

Figures 1 and 2. Vitellogenic oocyte showing lipid globules (lg), acidophilic yolk granules (yg), and the zona radiata (r) and follicular layer (f). (fig. 1 Haematoxylin-eosin. 250x; fig. 2 Haematoxylin-VOF. 400x.

Figuras 1 y 2. Ovocitos vitelogénicos donde se observan los glóbulos lipídicos (lg), gránulos de vitelo (yg), zona radiada (r) y envuelta folicular (f). (fig.1 Hematoxilina-eosina. 250x; fig. 2 Hematoxilina-VOF. 400x.

Figure 3. Phospholipids/glycolipids in the yolk granules, zona radiata and follicular layer. Absence of sudanophilia in lipid globules (neutral lipids dissolved during paraffin-embedding procedure). Sudan Black B. 400x.

Figura 3. Fosfolípidos/glicolípidos en los gránulos de vitelo, zona radiada y envuelta folicular. Ausencia de sudanofilia en los glóbulos lipídicos (lípidos neutros disueltos durante el proceso de inclusión en parafina). Negro Sudán B. 400x.

Figure 4. Weak and moderate PAS reactivity in the yolk granules and zona radiata respectively, and negativity in lipid globules. PAS reaction. 250x.

Figura 4. Reactividad débil y moderada al PAS en los gránulos de vitelo y zona radiada, respectivamente, y negatividad en los glóbulos lipídicos. Reacción PAS. 250x.

Figure 5. Proteins in the yolk granules, zona radiata and follicular layer. Bromophenol Blue reaction. 250x.

Figura 5. Presencia de proteínas en los gránulos de vitelo, zona radiada y envuelta folicular. Reacción Azul de Bromofenol. 250x.

Figure 6. Proteins rich in disulphide groups (-S-S-) in the yolk granules, intergranular cytoplasm, zona radiata and follicular layer. Thyoglicollate-Ferric ferricyanide-Fe III technique. 250x.

Figura 6. Proteínas ricas en grupos disulfuro (-S-S-) en los gránulos de vitelo, citoplasma intergranular, zona radiada y envuelta folicular. TioglicólicoFerricianuro-Férrico-Fe III. 250x. 

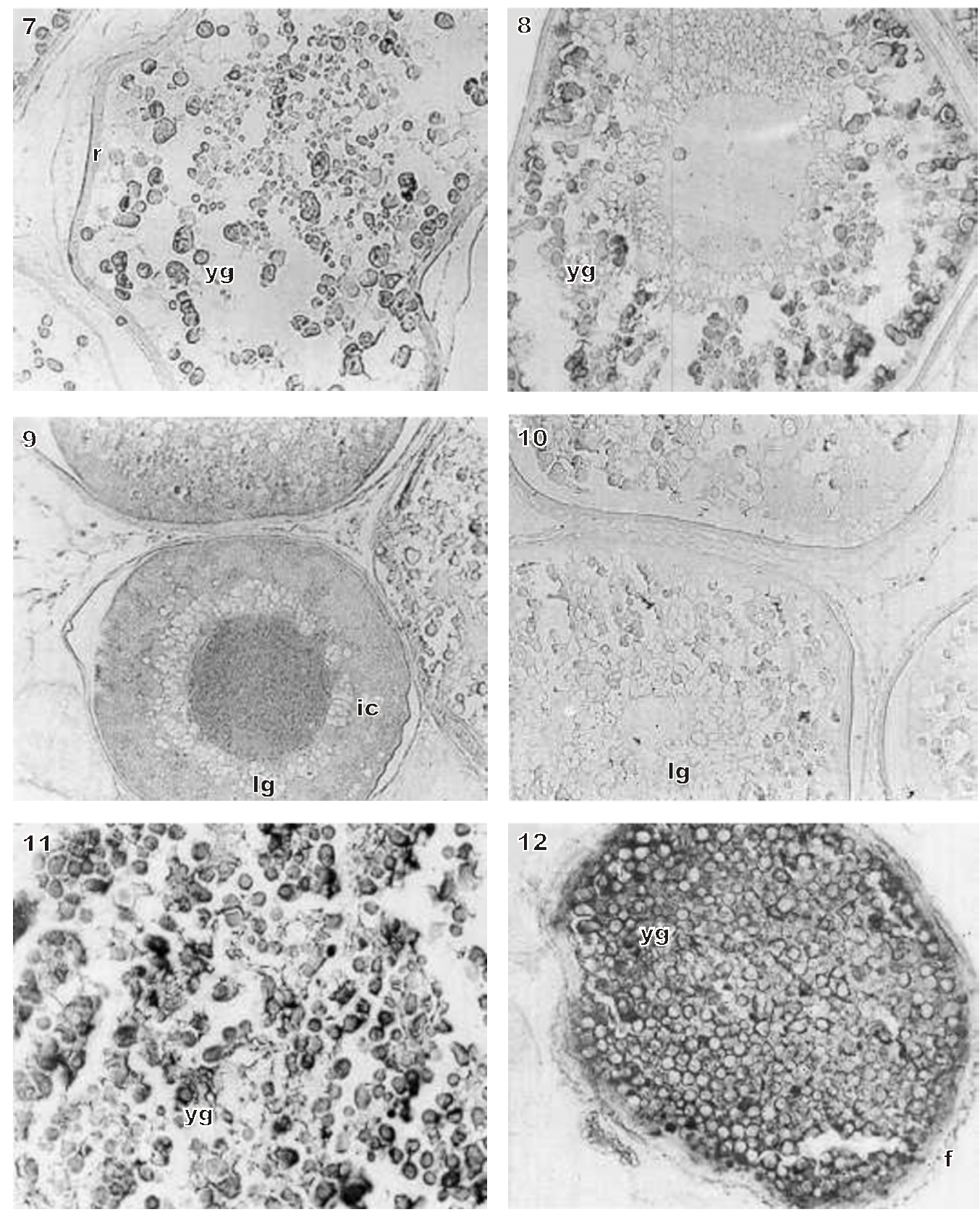

Figure 7. Proteins rich in tryptophan in a vitellogenic oocyte with a strong reaction in the yolk granules (yg), as well as within the intergranular cytoplasm. P-dimethylaminobenzaldehyde technique. 250x. r = zona radiata.

Figura 7. Proteínas ricas en triptófano en un ovocito vitelogénico, con una intensa reacción en los gránulos de vitelo (yg) y en el citoplasma intergranular. P-dimetilaminobenzaldehido. 250x. $r=$ zona radiada.

Figure 8. Glycoconjugates containing GalNAc sugar residues in the yolk granules, intergranular cytoplasm and follicular layer. DBA (N-acetyl-D-galactosamine -GalNAc-) lectin technique. 250x.

Figura 8. Glicoconjugados con residuos glucídicos de GalNAc en los gránulos de vitelo, citoplasma intergranular y envuelta folicular. Lectina DBA (N-Acetil-Dgalactosamina -GalNAc-). 250x.

Figure 9. Weak reaction of glycoconjugates containing Man and/or Glc sugar residues in the yolk granules, and moderate staining within the intergranular cytoplasm (ic). ConA (Mannose -Man- and/or Glucose -Glc-) lectin technique. 250x. Ig = lipid globules.

Figura 9. Reacción débil de glicoconjugados con residuos de Man y/o Glc en los gránulos de vitelo, y moderada tinción en el citoplasma intergranular (ic). Lectina Con A (Manosa -Man- y/o Glucosa -Glc-). 250x. Ig = glóbulos lipídicos

Figure 10. Weak reaction of glycoconjugates containing L-Fuc sugar residues. UEA-I (L-Fucose -L-Fuc-) lectin technique. 250x.

Figura 10. Intensidad débil de glicoconjugados conteniendo residuos de L-Fuc. Lectina UEA-I (L-Fucosa -L-Fuc-). 250x.

Figure 11. Calcium in yolk granules and within the intergranular cytoplasm of a vitellogenic oocyte. Cobalt-Amonium sulphide method. 250x.

Figura 11. Presencia de calcio en los gránulos de vitelo y en el citoplasma intergranular de un ovocito vitelogénico. Método Cobalto-Sulfuro Amónico. 250x.

Figura 12. Vitellogenin (VTG) in the yolk granules, intergranular cytoplasm and follicular layer (f). Anti-seabass VTG antisera. 250x.

Figura 12. Vitelogenina (VTG) en los gránulos de vitelo, citoplasma intergranular y envuelta folicular (f). Anti-VTG de robalo. 250x. 

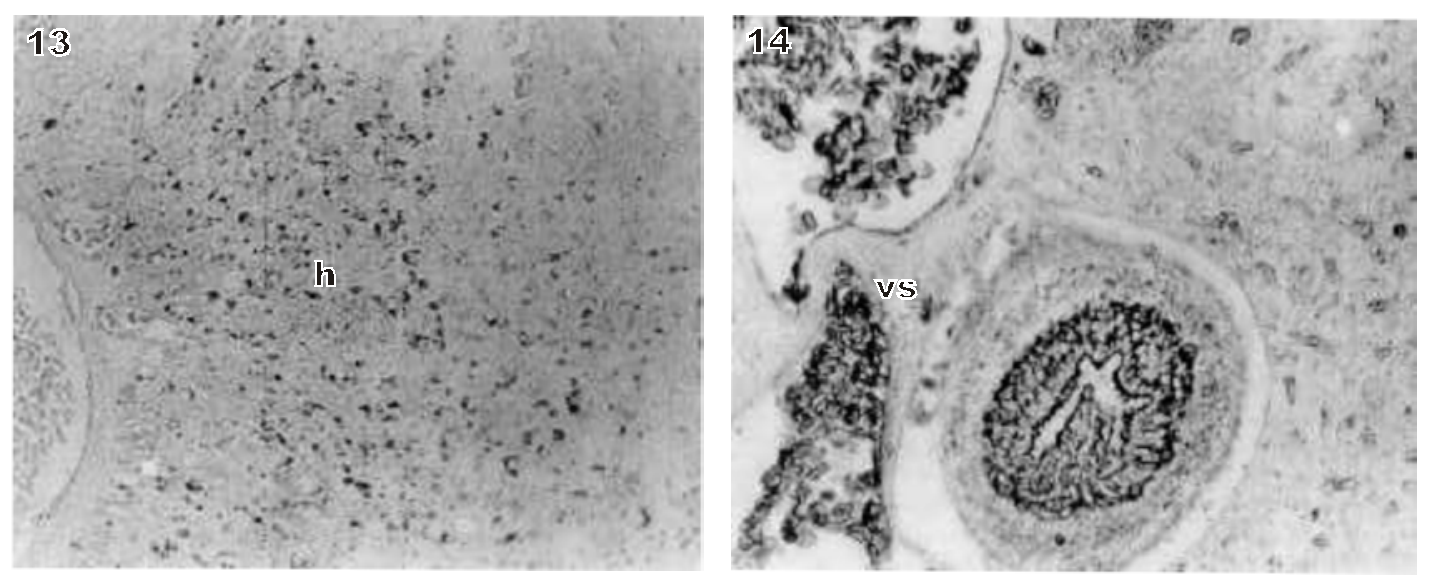

Figure 13 and 14. Presence of VTG in hepatocytes (h) and vascular system (vs) in the liver of a vitellogenic female (on May). Anti-seabass VTG antisera. 250x.

Figure 13 y 14. Presencia de VTG en los hepatocitos (h) y sistema vascular (vs) del hígado de una hembra vitelogénica. Anti VTG de robalo. 250x.

commercial VTG antisera obtained positive results in the liver of the brown trout, Salmo trutta fario females; while no staining was detected in the liver of males. In addition to VTG, an apparent precursor of the vitelline envelope (VEP) has been identified immunochemically in some teleost fish (Hamazaki et al., 1985; Murata et al., 1994). In Diodon holocanthus, Fujita et al. (1998) showed that yolk granules and the vitelline envelope enclosing developing oocytes were immunostained with anti-Diodon holocanthus VTG and with anti-VEP. It was noted that the appearance of VEP precedes that of VTG in the plasma of rainbow trout (Hyllner et al., 1994).

Yolk granules present in the vitellogenic oocytes of bluefin tuna contained proteins, neutral glycoproteins and lipids (glycolipids, phospholipids). Similar results were observed in Sparus aurata (Sarasquete et al., 1993a) and Seriola dumerili (Grau et al., 1996). However, the yolk granules present in vitellogenic oocytes of goldfish and seabass were PASnegative (Khoo, 1979; Mayer et al., 1988). In Oryzias latipes, Lipsetta obscura and Solea senegalensis, yolk granules contain acid glycoproteins (Aketa, 1954; Yamamoto, 1956; Gutiérrez et al., 1985) which were not observed in the yolk granules but within the intergranular cytoplasm of Thunnus thynnus oocytes. In rabbifish, the post-vitellogenic oocytes contain several large lipid droplets made of neutral lipids and glycolipids. In this species, the protein yolk consists of neutral and slightly basic proteins and this yolk does not contain lipids (Lahnsteiner and Patzner, 1999). However, in Sparus aurata, Halobatrachus didactylus and Seriola dumerili (Sarasquete et al., 1993a; Muñoz-Cueto et al., 1996; Grau et al., 1996), as was observed in bluefin tuna oocytes, lipid globules present in initial vitellogenic oocytes contain only neutral lipids. According to different authors, the lipid droplets present in eggs are energy sources, and do not influence their buoyancy (Mommsen and Walsh, 1988; Heming and Buddington, 1988). observada en la capa folicular es de dudosa interpretación, posiblemente debido, como sugieren Abraham et al. (1984), a que esta capa no está relacionada directamente con la transferencia de material exógeno hacia el interior de los ovocitos.

Los hepatocitos han sido identificados como fuente exógena de vitelogenina, mientras que la sangre constituye el vehículo de transferencia de la VTG entre el hígado y el ovario (Wallace, 1978). En hembras de atún rojo, la anti-VTG ha sido positiva en los gránulos de vitelo, la envuelta folicular, y el citoplasma intergranular de los ovocitos vitelogénicos, así como en el hígado (sistema vascular y hepatocitos). Wahli et al. (1998), utilizando diferentes anticuperpos comerciales mono y policlonales contra la vitelogenina, observaron resultados positivos en el hígado de las hembras de Salmo trutta fario y resultados negativos en los machos. Además de la VTG, un aparente precursor de la envuelta vitelínica (VEP) ha sido identificado inmunocitoquímicamente en algunos teleósteos (Hamazaki et al., 1985: Murata et al., 1994). En Diodon holocanthus, Fujita et al. (1998) observaron que los gránulos de vitelo y la envuelta vitelinica que rodeaba a los ovocitos era teñida con anti-VTG y anti-VEP. En el plasma de la trucha, la aparición de VEP precedía a la de VTG (Hyllner et al., 1994).

Los gránulos de vitelo presentes en los ovocitos vitelogénicos del atún contienen proteínas, glicoproteínas neutras y lípidos (glicolípidos, fosfolípidos). Resultados similares fueron observados en la dorada, Sparus aurata (Sarasquete et al., 1993a) y Seriola dumerili (Grau et al., 1996). Sin embargo, los granos de vitelo presentes en los ovocitos del pez dorado y el robalo eran negativos al PAS (Khoo, 1979; Mayer et al., 1988). En Oryzias latipes, Lipsetta obscura y Solea senegalensis, los gránulos de vitelo contienen glicoproteínas ácidas (Aketa, 1954; Yamamoto, 1956; Gutiérrez et al., 1985), las cuales no fueron observadas en los gránulos de vitelo del atún rojo, pero 
As was pointed above, the egg formation process in teleosts is accompanied by an active incorporation of exogenously synthesized VTG into growing oocytes in the ovary. In bluefin tuna females, VTG was detected in yolk granules, intergranular cytoplasm and the follicular envelope of the vitellogenic oocytes, as well as in the hepatic vascular system, but weakly in the cytoplasm of hepatocytes. Similar results were observed in Sparus aurata vitellogenin oocytes (Sarasquete et al., 1993b, c).

As in other species (Grau et al., 1996), the internal layer of the zona radiata layer of vitellogenic oocytes of Thunnus thynnus contain neutral glycoproteins. The presence of proteins rich in different aminoacids and especially rich in cystine suggests that most of the protein material of this multilamellar layer was determined by the formation of disulphide bonds (Hagenmaier, 1973; Mayer et al., 1988). Hamor and Garside (1973), in the zona radiata of Salmo salar oocytes, observed proteins, mucopolysaccharides, phospholipids, cholesterol, DNA and RNA, as well as oxidative enzymes such as peroxidase, uricase, etc. Studies in other fish species (Tesoriero, 1977) have shown that the external layer of the zona radiata is rich in polysaccharides, whereas the inner layer is rich in proteins. In Carassius auratus (Khoo, 1979) and Dicentrarchus labrax (Mayer et al., 1988) polysaccharides adhere to the outer layer which might contribute to the adhesion of the eggs. Recently, in eggs of Siganus rivulatus, Lahnsteiner and Patzner (1999) indicated that the chorion consisted exclusively of proteins. The follicular envelope of the tuna oocytes contain vitellogenin, lipids, calcium and proteins, and the zona radiata is formed mainly by proteins but few lipids and neutral glycoproteins were also observed in this layer.

At the present, and during two annual reproductive cycles, we have (and/or we are) analysing the morphohistological characteristics of the gonads and the liver of males and females (oocyte-types and frecuency, phases of spawning, regression, resting, spermatogenesis, spermiation, etc.), as well as the presence and variation of sexual hormones and vitellogenin in serum gonads and liver of the bluefin tuna, Thunnus thynnus, in wild specimens and in those treated with synthetic GnRHimplants.

\section{Acknowledgements}

The authors thank Isabel Viaña, Juan B. Ortiz, Africa García-García and Juana Arellano for their technical assistance. This study is supported by Feder-Project-Spain (IFD970880-C05-01).

\section{References}

Abraham, M., Hilge, V., Lison, S. and Tibiya, H. (1984). The cellular envelope of oocyte in teleosts. Cell and Tissue Res., 235: 403410.

Albaret, J.J. (1977). Reproduction of the yellowfin tuna (Thunnus albacares) in the Gulf of Guinea. Cah. ORSTON (Oceanogr.), 15: 389-419. que si se han localizado en el citoplasma intergranular de los ovocitos vitelogénicos. En Siganus rivulatus, los ovocitos postvitelogénicos contienen varias y grandes gotas lipídicas compuestas por lípidos neutros y glicolípidos. En esta especie, el vitelo proteico, carente de lípidos, contiene proteínas neutras y básicas (Lahsteiner y Patzner, 1999). Sin embargo, en Sparus aurata, Halobatrachus didactylus y Seriola dumerili (Sarasquete et al., 1993a; Muñoz-Cueto et al., 1996; Grau et al., 1996), como se observa en el atún rojo, las vacuolas lipídicas presentes en los ovocitos en vitelogénesis inicial sólo contienen lípidos neutros. Según differentes autores (Mommsen y Walsh, 1988; Heming y Buddington, 1988), las gotas lipídicas de los huevos de peces son una fuente energértica y no contribuyen a su capacidad para la flotación.

Como se comentó anteriormente, el proceso de formación del huevo en teleósteos es acompañado por una activa incorporación de VTG sintetizada de forma exógena e incorporada en el ovario durante el crecimiento de los ovocitos. La VTG ha sido observada en los granulos de vitelo, el citoplasma intergranular y la envuelta folicular de ovocitos vitelogénicos del atún rojo, así como en el sistema vascular y, débilmente, en el citoplasma de los hepatocitos. Resultados similares han sido observados en ovocitos vitelogénicos de Sparus aurata (Sarasquete et al., 1993b,c).

Como se observa en otras especies (Grau et al., 1996), la capa interna de la zona radiada de los ovocitos vitelogénicos de Thunnus thynnus contiene glicoproteínas neutras y proteínas ricas en diferentes aminoácidos y especialmente ricas en cistina, lo que sugiere que la mayor parte del material proteináceo de esta capa multilamelar es determinada por la formación de puentes disulfuro (Hagenmaier, 1973; Mayer et al., 1988). Hamor y Garside (1973) en la capa radiada de los ovocitos de Salmo salar, observaron proteínas, mucopolisacáridos, fosfolípidos, colesterol, DNA y RNA, así como enzimas oxidativas: peroxidasa, uricasa, etc. En otros teleósteos, Tesoriero (1977) observó que la porción externa de la capa radiada contiene polisacáridos, mientras que la interna es rica en proteínas. En Carassius auratus (Khoo, 1979) y Dicentrarchus labrax (Mayer et al., 1988), los polisacáridos están unidos a la capa externa de la zona radiada contribuyendo a la adhesión de los huevos. Recientemente, Lahnsteiner y Patzer (1999) observaron que el corion de Siganus rivulatus contiene proteínas exclusivamente. La envuelta folicular de los ovocitos de atún contiene vitelogenina, lípidos, calcio y proteínas y la capa radiada está formada fundamentalmente por proteínas, conteniendo también escasos lípidos y glicoproteínas neutras.

Actualmente, y durante dos ciclos anuales de reproducción, hemos (y/o estamos) analizando las características histomorfológicas de las gónadas y el hígado de machos y hembras (tipo de oocitos y frecuencia, fases de puesta, regresión, reposo, espermatogénesis, espermiación, etc.), así como la variación de hormonas y vitelogenina en suero, gónadas e hígado del atún rojo, Thunnus thynnus, en ejemplares salvajes y tratados con implantes sintéticos de GnRH. 
Aketa, K. (1954). The chemical nature and the origin of the cortical alveoli in the egg of the medaka, Oryzias latipes. Embriologia, 2: 63-66.

Alvarez, M. (1993). Estudio histoquímico y bioquímico de lípidos durante el ciclo reproductivo de Halobatrachus didactylus (Schneider, 1801) en la Bahía de Cádiz. Tesis Doctoral. Universidad de Cádiz. Facultad de Medicina, 218 pp.

Bancroft, J.D. and Stevens, A. (1990). Theory and practice of histological techniques. (Bancroft, J.D., Stevens, A. and Turner, D.R., eds.). Churchill Livingstone. Edinburgh London Melbourne and New York. $3^{\mathrm{a}}$ ed., $726 \mathrm{pp}$.

Blanco, M.A. (1991). Estudio histológico, histoquímico y bioquímico durante la reproducción del pez sapo, Halobatrachus didactylus, (Schneider, 1801) de la Bahía de Cádiz. Tesis Doctoral. Universidad de Cádiz. Facultad de Medicina, 200 pp.

Cárdenas, S., Pascual, E., González de Canales, M.L., Piñuela, C., Rendón, C., Rodríguez-Gomez, F.J. and Sarasquete, C. (2001). Contribución a la biología reproductiva del atún rojo, Thunnus thynnus. Estudio de la espermatogénesis. VIII Congreso Nacional de Acuicultura. Santander (Spain), pp. 166-169.

Chopra, H.C. (1958a). A morphological and histochemical study of the oocytes in the fish, Ophiocephalus punctatus, with particular reference to lipids. Quat. J. Micr. Sci., 19: 149-158.

Chopra, H.C. (1958b). Morphological and histochemical study of oocytes of the fish, Barbus punctiusticto with particular reference to lipids. Res. Bull. Punjab Univ., 152: 211-221.

Davila, C. (1985). Túnidos y demás Escómbridos Mundiales. MAPA, Madrid. 223 pp.

Dasmahapatra, A.K. and Medda, A.K. (1982). Effect of estradiol dipropionate and testosterone propionate on the glycogen, lipid and water contents of liver, muscle and gonad of male and female (vitellogenic and non vitellogenic) singi fish Heteropneustes fossilis. Gen. Comp. Endocrinol., 48: 476-484.

De Vlaming, V.L., Wiley, H.S., Delahunty, G. y Wallace, R.A. (1980). Goldfish (Carassius auratus) vitellogenin: induction, isolation, properties and relationships to yolk proteins. Comp. Biochem. Physiol., 67B: 613-623.

Fujita, T., Takemura, A. and Takano, K. (1998). Immunochemical detection of precursor proteins of yolk and vitelline envelope, and their annual changes in the blood of Diodon holocanthus. J. Fish Biol., 52: 1229-1240.

García-García, A. (1995). Estudio del ciclo reproductivo de peces teleósteos en el Golfo de Cádiz: Caracterización de las gonadotropinas de Thunnus thynnus y esteroideogenesis en el ovario de Fundulus heteroclitus. Ph. D. Thesis. Universidad de Cádiz.

Gillis, D.J. and McKeown, B.A. (1990). Physiological and histological aspects of late oocyte provisioning, ovulation, and fertilization in Pacifici herring (Clupea harengus pallasi). Can. J. Fish. Aquat. Sci., 47: 1505-1512.

González de Canales, M.L., Blanco, M. and Sarasquete, C. (1992). Carbohydrate and protein histochemistry during oogenesis in Halobatrachus didactylus (Schneider, 1801) from the Bay of Cádiz (Spain). Histochemical Journal, 24: 337-344.

Grau, A. (1992). Aspectos histológicos, ciclo reproductor y principales procesos patológicos de Seriola dumerili, Risso 1810 (Carangidae). Tesis Doctoral. Univ. Autónoma de Barcelona 451 pp.

Grau, A., Crespo, S., Riera, F., Pou, S. and Sarasquete, M.C. (1996). Oogenesis in the amberjack Seriola dumemrili Risso, 1810. An

\section{Agradecimientos}

Los autores quieren expresar su agradecimiento a Isabel Viaña, Juan Bosco Ortiz, Africa García-García y Juana Arellano por su valiosa ayuda técnica. Este estudio forma parte del proyecto Feder-España (IFD97-0880-C05-01).

Traducido al español por los autores.

histological, histochemical and ultrastructural study of oocyte development. Sci. Mar., 60: 391-406.

Guraya, S.S. (1965). A comparative histochemical study of fish, Channa maruleus and amphibian, Bufo stomaticus oogenesis, $Z$. Zellforsch. Mikroskop. Anat., 65: 662-700.

Gutiérrez, M. (1990). Nuevos colorantes biológicos y citohistoquímica de la coloración. Tesis doctoral. Facultad de Ciencias. Universidad de Cádiz. 239 pp.

Gutiérrez, M., Sarasquete, M.C. and Rodríguez, R.B. (1985). Caracteres citohistoquímicos de carbohidratos y proteínas durante la ovogénesis del lenguado, Solea senegalensis (Kaup, 1858). Inv. Pesq,. 49 (3): 353-363.

Hagenmaier, H. (1973). The hatching process in fish embryos: III. The structure, polysaccharide and protein cytochemistry of the chorion of the trout egg, Salmo gairdneri (Rich.) Acta Histochem. Bd., 47: 61-69.

Hamazaki, T., Iuchi, I. and Yamagami, K. (1985). A spawning femalespecific substance reactive to anti-chorion (egg-envelope) glycoprotein antibody in the teleost, Oryzias latipes. J. Exper. Zool., 235: 269-239.

Hamor, T. and Garside, E.T. (1973). Peroxisome-like vesicles and oxidative activity in the zona radiata and yolk of the ovum of the Atlantic salmon, Salmo salar L. Comp. Biochem. Physiol., 45B: $147-151$.

Hara, A. and Hirai, H. (1978). Comparative studies on immunochemical properties of female-specific serum protein and egg yolk proteins in rainbow trout, Salmo gairdneri. Comp. Biochem. Physiol., 59B: 339-343.

Haux, C. and Norberg, B. (1985). The influence of estradiol-17 on the liver content of proteins, lipids, glycogen and nucleic acids in juvenile rainbow trout, Salmo gairdneri. Comp. Biochem. Physiol., 81B: $275-279$.

Heming, T.A. and Buddington, R.K. (1988). Yolk absorption in embryonic and larval fishes. In: W.S. Hoar and D.J. Randall (eds.), Fish Physiology. The Physiology of Developing Fish. Eggs and Larvae.Vol. 11(A), Academic Press, Inc. New York, pp. 407-446.

Hirota, H. and Morita, M. (1976). An instance of the maturation of 3 full years old bluefin tuna cultured in the floating net. Bull. Jap. Soc. Sci. Fish., 42: 939.

Hyllner, S.J., Silversand, C. and Haux, C. (1994). Formation of the vitelline envelope precedes the active uptake of vitellogenin during oocyte development in the rainbow trout, Oncorhynchus mykis. Mol. Reprod. Develop., 39: 166-175.

Khoo, K.H. (1979). The histochemistry and endocrine control of vitellogenesis in goldfish ovaries. Can. J. Zool., 57: 617-626.

LaFleur, G.J. Byrne, B.M., Kanungo, J., Nelson, L.D. Greenberg, R.M. and Wallace, R.A. (1995). Fundulus heteroclitus vitellogenin: The deduced primary structure of a piscine precursor to noncrystalline, liquid-phase yolk protein. J. Mol. Evol., 41: 505-521. 
Lahnsteiner, F. and Patzner, R.A. (1999). Characterization of spermatozoa and eggs of the rabbitfist. J. Fish Biol., 55: 820-835.

Lange, R.H., Richter, H.P., Riehl, R., Zierhold, K., Trandaburu, T. and Magdowski, G. (1983). Lipovitellin-phosvitin crystals with orthorhombic features: thin-section electron microscopy, gel electrophoresis, and microanalysis in teleost and amphibian yolk platelets and a comparison with other vetebrates. J. Ultrastr. Res., 83: $122-140$.

Mañanós, E., Zanuy, S., Le Menn, F., Carrillo M. and Núñez, J. (1994). Sea bass (Dicentrarchus labrax L.) vitellogenin. I. Induction, purification and partial characterization. Comp. Biochem. Physiol. Vol. 10B (2): 205-216.

Martoja, R. and Martoja-Pierson, M. (1970). Técnicas de Histología Animal. Toray Masson. Barcelona, $350 \mathrm{pp}$.

Mayer, I., Shackley, S.E. and Ryland, J.S. (1988). Aspects of the reproductive biology of the bass, Dicentrarchus labrax L. I. An histological and histochemical study of oocyte development. J. Fish Biol., 33: 609-622.

Mommsen, T.P. and Walsh, P.J. (1988). Vitellogenesis and oocyte assembly. In: W.S. Hoar and D.J. Randall (eds.), Fish physiology Vol. 1A, Academic Press, New York, pp. 347-406

Mourente, G., Megina, C. and Diaz-Salvago, E. (2002). Lipids in female northern bluefin tuna, Thunnus thynnus during sexual maturation. Fish Physiol. Biochem. 24: 351-363.

Muñoz-Cueto, J.A., Alvarez, M. Blanco, M. González de Canales, M.L., García-García., A. and Sarasquete, C. (1996). Histochemical and biochemical study of lipids during the reproductive cycle of the toadfish, Halobatrachus didactylus (Schneider, 1801). Sci. Mar., 60: 289-296.

Murata, K., Iuchi and Yamagami, K. (1994). Synchronous production on the low- and high-molecular-wight precursosrs of the egg envelope subunits, in response to estrogen administration in the teleost fish, Oryzias latipes. Gen. Comp. Endocrinol., 95: 232239.

Ng, B.T. and Idler, D.R. (1983). Yolk formation and differentiation in teleost fishes. In: W.S. Hoar, D.J. Randall and E.M. Donaldson (eds.), Reproduction, Part A: Endocrine Tissues and Hormones, Academic Press. Orlando, pp. 372-404.

Pearse, A.G.E. (1985). Histochemistry. Theoretical and Applied. Vol. 2. Analytic Technology, 4th ed. Churchill Livinstone, New York, NY, 1055 pp.

Rodríguez-Roda, J. (1957). Crecimiento relativo del atún, Thunnus thynnus (L.), de Barbate. Inv. Pesq., 9: 33-64.

Rodríguez-Roda, J. (1964). Biología del atún (Thunnus thynnus (L.)) de la costa sudatlántica de España. Inv. Pesq., 25: 33-146.

Rodríguez-Roda, J.- 1967. Fecundidad del atún (Thunnus thynnus (L.)) de la costa sudatlántica de España. Inv. Pesq., 31: 33-52.

Rosety, M., Blanco, M., González de Canales, M.L., Grau, A. and Sarasquete, M.C. (1992). Biochemical parameters during reproduction of the toad fish, Halobrachus didactylus (Schneider, 1801). Sci. Mar., 56: 87-94.

Sarasquete, C., Polo, A., Pascual, E. and Yúfera, M. (1993a). Histochemistry of proteins, lipids and carbohydrates in the yolk of oocytes, eggs and larvae of seabream, Sparus aurata L. In: B. Walther, and T. Fyhn (eds.), Physiological and Biochemical Aspects of Fish Development, University of Bergen. Bergen. Norway, pp. 309-314.

Sarasquete, C., Muñoz-Cueto, J.A., González de Canales, M.L. y García-García, A. (1993b). Localización inmunohistoquímica de vitelogenina durante la reproducción de Sparus aurata L. II Symposium Internacional Aspectos Básicos de la ImunoCitoquímica aplicada. Chiclana, Cádiz. Spain.

Sarasquete, M.C., Muñoz Cueto, J.A., González de Canales, M.L. and Rodríguez, R.B. (1993c). Histological, histochemical and immunohistochemical characteristics during oogenesis of Solea senegalensis (Kaup, 1858) in the gulf of Cádiz (Spain). Actas IV Congreso Nac. Acuicultura. 49-54.

Sarasquete, C., Cárdenas, S., González de Canales, M.L and Pascual, E. (2002). Oogenesis in the bluefin tuna, Thunnus thynnus L. A histological and histochemical study. Histol. Histopathol., 17: 775-788.

Schaefer, K.M. (1996). Spawning time, frequency, and batch fecundity of yellowfin tuna, Thunnus albacares, near Clipperton Atoll in the eastern Pacific Ocean. Fish. Bull., 94: 98-112.

Selman, K. and Wallace, R.A. (1982). Oocyte growth in the sheepshead minnow: Uptake of exogenous proteins by vitellonec oocytes. Tissue Cell., 4: 555-571.

Selman, K. and Wallace, R.A. (1983). Oogenesis in Fundulus heteroclitus. III. Vitellogenesis. J. Exp. Zool., 226: 441-457.

Selman, K. and Wallace, R.A. (1989). Cellular aspects of oocyte growth in teleost. Zool. Sci., 6: 211-231.

Selman, K., Wallace, R.A., Sarka, A. and Xiaoping Qi. (1993). Stages of oocyte development in the zebrafish, Brachydanio rerio. J. Morphol., 218: 203-2224.

Singh, P.B., and Singh, T.P. (1990). Seasonal correlative changes between sex steroids and lipid levels in the freshwater female catfish, Heteropneustes fossilis. J. Fish Biol., 37: 793-802.

Susca, V., Corriero, A., Bridges, C.R and Metrio, G.De. (2001). Study of the sexual maturity of female bluefin tuna: purification and partial characterization of vitellogenin and its use in an enzymeliked immunosorbent assay. J. Fish. Biol., 58: 815-831.

Tesoriero, J.V. (1977). Formation of the chorion (zona pellucida) in the teleost, Oryzias latipes. II. Polysaccharide cytochemistry of early oogenesis. J. Histochem. Cytochem., 25: 1376-1380.

Wahli, T., Meier, W. Segner, H. and Burkhardt-Holm, P. (1998). Immunohistochemical detection of vitellogenin in male brown trout from Swiss rivers. Histochem. J., 30: 753-758.

Wallace, R.A. (1978). Oocyte growth in non mammalian vertebrates. In: R.E. Jones (ed.), Vertebrate Ovary. Plenum Press, New York. pp. 469-502.

Yamamoto, K. (1956). Studies on the formation of eggs. I. Annual cycle in the development of ovarian eggs in the flounder, Lipsetta obscura. J. Fac. Sci. Hokkaido Univ., 12: 362-373. 